\section{BOOKK REVIIIIS}

\section{Language}

\section{Affleck (J) and Letchford (C)}

OCR Anthology for Classical Greek GCSE pp. 270. Bloomsbury

Publishing, 2016 Paperback, £16.99 ISBN 978-1-47426-548-5

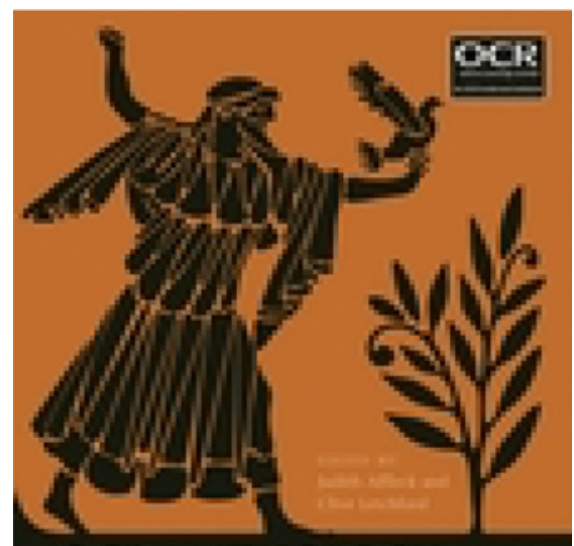

OCR ANTHOLOGY raE

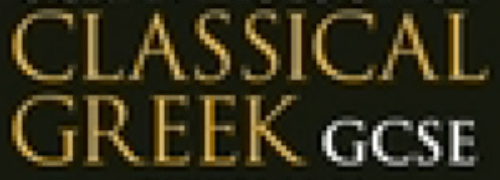

Given the price, this is a beautifully produced textbook, with attractive embossing on front and back covers, a lovely thing to hold and behold. It is a co-production of Bloomsbury and the OCR examination board and is one of a series created for the new specifications. An innovation, and one which most purchasers will welcome, is that all the prescribed texts until 2023 are included. As well as the obvious budgetary advantage, this will furnish teachers with other passages which can be used as 'unseens'.

To start with, there are some introductory pages, including Tips for Translation and Discussing Literary Style; the former is handy, the latter a good starting point for teachers. The OCR Defined Vocabulary List is indexed at the back. The book follows the pattern familiar from the Cambridge and Oxford Latin Anthologies (text on the left, notes and vocabulary on the facing page) and this will be, of course, a major advantage, not least in terms of time, to both teacher and pupil; in addition, key GCSE words are introduced, piecemeal, at the bottom of each page of text. Also useful are the typical questions to be found on most pages, a mixture of the factual and the thought-provoking. Each line of text has a corresponding note or notes, with a few exceptions.

Another striking and useful innovation is that the nominative and finite verb in each clause are coloured light-blue and dark-blue, respectively; this, again, will cut down on time spent in dissecting sentences, but this reviewer is left slightly uneasy by so much help being given to the pupil. The editors also acknowledge other useful aids for pupils, including those that come via the internet.

Apart from a small number of typos (e.g., 460, rather than 480, in the Timeline, for the start of the Classical period) and

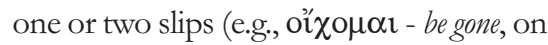
page 95 , rather than have gone), the text is very accurate. There is a curious inconsistency of spelling, there being just a few Americanisms; this may be due to the dual authorship. One minor irritation is the Map of the Ancient Mediterranean which is badly planned and badly printed - Eleusis, Halicarnassus and Macedon are misplaced, Samosata and Thebes are omitted and Cairo is added, I know not why.

\section{Terry Walsh, Ratcliffe College}

Campbell (M), Colborn (R), Daniele (F), Gravell (B), Harden (S), Kennedy (S), McCullagh (M), Paterson (C), Taylor (J) and Webster (C)

OCR Anthology for Classical Greek AS and $A$ level pp. viii + 504. Bloomsbury Publishing, 2016 Paperback, £25.99 ISBN 978-1-47426-602-4

A collaboration of ten or more scholars, this vast co-production of Bloomsbury

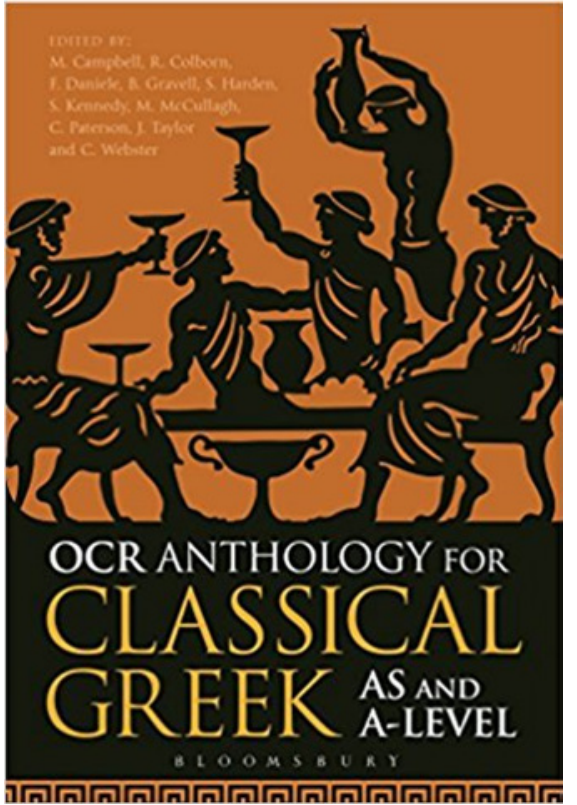

and OCR sets out to cover all bases for the new Greek literature specification at both AS (H044) and A level (H444), for 2017 until 2019. It contains selections from: Thucydides, Histories 4, Plato's Apology, Xenophon's Memorabilia, Homer's Odyssey 9 and 10, Sophocles' Antigone and Aristophanes' Acharnians.

The volume is planned as a complete vademecum for both pupil and teacher, complete, as it is, with text, introductions to authors, comprehensive notes, glossaries and vocabularies; as such it is real value for money. What is more, it seems well-bound and should survive the rough-and-tumble of school. Lastly, a website accompanies the book, although registration, albeit free, is still a little tricky (www.bloomsbury.com/OCR-editions).

The book is, refreshingly, mainly the offspring of classroom teachers and is all the more welcome for that. It is designed to be simple and easy to use and the language is sometimes strikingly modern ('bullshit'), sometimes slightly archaic ('yes, verily'). The different AS and A level selections are marked by obvious corner-labels at the foot of each page - except for the Odyssey selections, for some reason.

As I stated above, this volume is compendious in its attempt to cover not only the text itself, but also every aspect of the background. Herewith, however, I come to a slightly negative point; there is page after page thick with text (albeit 1.5-spaced), which is occasionally relieved by breaks and/or English headings (e.g., Antigone) or not relieved by any breaks at 
all (Odyssey). Some may not mind this, but it will initially intimidate others. I could find no typos or other errors.

Terry Walsh, Ratcliffe College

\section{Rico (C) and Daise (M)}

\section{Speaking Ancient Greek as a Living Language: Level One, Student's Volume, Polis Institute Press (2015).}

\section{$\pi$ POLIS}
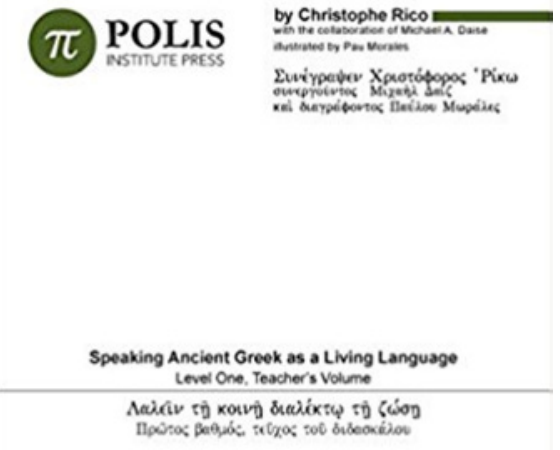

Polis
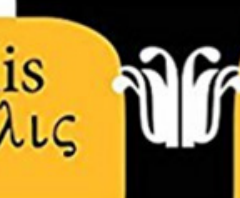

Speaking Ancient Greek as a Living Language offers a thoroughly different way to think about teaching and learning ancient Greek. The course focuses on Koine Greek from the First Century AD with a few modifications, not as an inferior language, but on the basis that there is enough of it to meet the needs of the method. The aim is to teach students through speaking and acting in Greek, in the way that is common for modern foreign languages. The Polis Institute describes its method as total physical response and total oral immersion, which in the UK might be known as the Direct Method. There is a long history for Latin being taught this way, including in the UK, but far less for ancient Greek.

Who speaks ancient Greek though? This book does not suggest that the direct method is helpful in enabling communication within a living community, but that it is the quickest and most effective way to bring about a fluency of understanding that will allow a student to read Greek texts with relative ease. These texts are necessarily limited to those composed in Koine, but, as is noted in the Foreword, this accounts for over $90 \%$ of extant ancient Greek texts (x); it does not, moreover, preclude the possibility of branching out into other dialects, and may even help students face these given their supposedly increased confidence in manipulating the language.

The book is divided into 20 chapters, extending the 12 from the original 2009

French edition. Grammar covered includes: the present and aorist of active, middle and passive verbs, including infinitives and imperatives, with a little attention paid to participles, $-\mu \mathrm{u}$ verbs, the five cases, first and second declensions (with minimal explanation of third declension endings), questions, adjectives and adverbs. Accents are included from the start, with an early explanation on how to try intoning their pitches. The formal focus is mainly on accidence rather than syntax, but a good range of basic sentence structures is used by the end of the book. It would take at least six months for a group to work through the book within UK educational frameworks. The amount of grammar covered is reasonable for younger groups, but would be too slow for e.g. ab initio undergraduates.

Chapters follow a relatively stable format. They open with a series of short instructions and phrases, repeated in the singular and plural to show differences. Short grammar explanations are interspersed with exercises $(\mu \varepsilon \lambda \varepsilon \tau \dot{\eta} \mu \alpha \tau \alpha)$ and readings, which often include filling in endings, filling in words from a list, or writing responses to prompts. Songs, games, and improvisations break up the reading and writing tasks. There is no reference dictionary. Each chapter has its own lexicon, where Greek terms are explained in Greek, almost all sufficiently clearly to be understood with ease.

At the end of Chapter1 there is an extract from John 1 (not marked as such), and other biblical quotations are occasionally used. The majority of readings, however, are made-up stories dealing with the main characters of the book. These characters are lively students and their families, who interact in a fun manner. As is often the case with simple language texts, they have to act in a relatively repetitive and juvenile fashion for the language to be understood. This risks being off-putting for an adult learner, but in general it is fun rather than patronising.
The majority of instructions and explanations are given in Greek, usually with an English translation. They are necessarily simple, and support a student in learning how to use the language as it is presented rather than understand it as a language system. With this key difference in the approach to language learning in mind, however, concepts are explained simply and reinforced well, so students would find themselves able to use the language confidently without excessive difficulty.

The textbook is designed for use in a class, but is also aimed at independent students. For the latter it would be very challenging to follow the book, as it really does rely on group engagement. There are lots of resources on both the Polis Institute website (http://www. polisjerusalem.org $/$ ) and their YouTube channel (search for Polis Institute).

Words are typed in red if they are important to the lesson in hand, which helps a student quickly navigate the sentences. Occasionally this breaks down with missed red letters, and also in some places the red is overused for marking instructions, which makes them harder to read. A few other typographical issues suggest that a second edition may be useful.

The Greek font is clear to read, unlike in many textbooks. Occasionally punctuation marks are awkwardly spaced (notably question marks, or vowels with initial breathing and accent combinations). The book is richly illustrated by Pau Morales, which helps bring not only the stories, but also the grammatical concepts to life.

This book is unlikely to replace standard textbooks in the UK, where the focus on learning ancient languages for examination purposes, with exams based around an established canon of texts and approaches to texts, is far too engrained. With its playful approach to active learning, however, it would be a very useful supplementary tool, supporting teachers in raising morale and enthusiasm. For those in less traditional learning contexts, such as adult education classes, it may prove more attractive. If its aim really is to enable students to read texts such as the New Testament with ease after a year, then a lot more vocabulary and syntax would need to be introduced in the following parts of the course, as this volume alone remains at a basic level. I am sufficiently 
interested in what the course has to offer, however, that I am now planning a trip to Jerusalem to experience the method in person.

\section{Cressida Ryan, University of Oxford}

\section{Chochola (J.W.) and Sprague (D.E.)}

\author{
A Latin Picture Dictionary for Everyone. \\ Lingua Latina Depicta. Pp. viii +205 , \\ ills. Mundelein, IL: Bolchazy- \\ Carducci Publishers, 2017. Paper, \\ US\$ 22. \\ ISBN 978-0-86516-749-0.
}

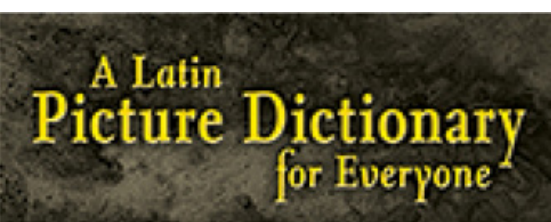

Lingua Latina Dericta

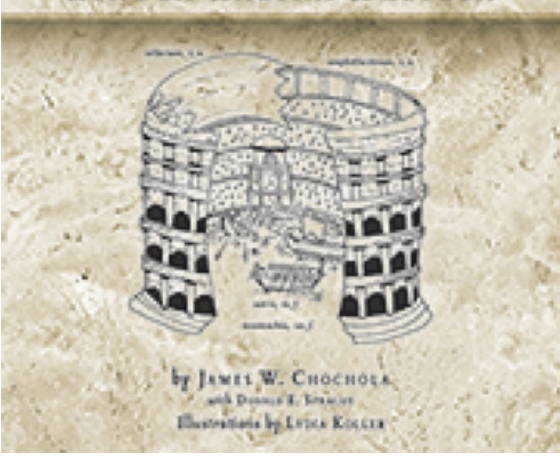

This book, as its title implies, is for 'everyone', not just school pupils, but also independent learners who are learning Latin ex nibilo. This is quite ambitious and a difficult balancing act to fulfil. As the authors state, their aim was not simply to produce a picture dictionary in alphabetical order, but to produce, 'a basic yet rather comprehensive list of vocabulary...', as well as exercises to reinforce understanding. The exercises have been kept deliberately 'basic' (the authors' choice of word) so that beginners are not put off, but are able to complete the exercises. Even so, they claim that they have included exercises of differing levels of complexity to 'accommodate readers with varying skills'. Again, this is always problematic and subjective. What one person finds too difficult another will find too easy.

There are 15 chapters comprising: 1 ) Animals and Numbers; 2) Colours; 3) Family; 4) Buildings; 5) Vehicles; 6)
Home; 7) Furniture; 8) Pastimes; 9) Professions; 10) The Military 11) Parts of the Body; 12) Clothing; 13) Kinds of Food and Shopping; 14) Preparing Food; and 15) The Arts. This is a standard choice of themes which are well chosen and provide a good start for beginners.

There are also four appendices which provide some background information on pronunciation and a basic introduction to grammar. These include : A)

Pronunciation of Classical Latin; B)

Major Parts of Speech and their Uses; C) How Latin Words Work: Nouns, Verbs, Adjectives and D) Grammatical Outline. Finally, there is a glossary of 'Additional Latin Vocabulary and Synonyms'.

The authors claim that 'a functional vocabulary is approximately $1,500-2,000$ words'. This book contains about 1,200. Choice of vocabulary is always going to be problematic - schools will want it specifically focused on the particular exams their students are taking. The authors claim to have 'used the word that appeared most frequently in the sources' - though, crucially, they don't say what these sources are. This becomes particularly noticeable in the section on 'military things', where some Latin words focus on modern life. For instance, on pages 110 and 111, which focus on the army, this is not the Roman army (though that is included elsewhere), but a modern army. So it contains words such as rocheta (= rocket) and helicopterum (helicopter), currus loricatus (a tank) and radios pyrios emittens (a bazooka, judging by the picture). Why you would need these words in a functioning Latin vocabulary is not quite clear. Most schools would probably want to skip this bit and go on to pages $115 \mathrm{ff}$. for the Roman military vocabulary (gladius, miles, hasta, galea, ballista and so on) which contains words which students are actually going to encounter in Latin texts. I'm pretty sure there were no tanks or rockets in Caesar's Gallic Wars, but maybe they are using a different MS, of which I am not aware. It would certainly explain how Caesar managed to conquer the Gallic tribes in such a short space of time.

Similarly, on shopping - there are both ancient and modern vocabulary pictures, so while independent learners, or those wishing to speak Latin as a living language, might want to use the modern translations, schools might prefer to stick to the ancient ones, unless it is for an after-school club; otherwise this will unnecessarily burden students with a superfluous vocabulary. Time is limited in schools and there is enough to get through without confusing the students with unnecessary vocabulary. On the other hand, by providing both modern and ancient pictures and vocabularies, the reader has a choice. It also gives students the opportunity to compare and contrast - to see how much things have changed (or not) over time.

There is a separate Teacher's Guide with the answers to the exercises (which I have not seen). If you are an independent learner it will be essential to buy this extra Teacher's Guide, or hire a tutor to check your answers to the exercises.

The layout of the book is good. The pictures and text are large, clear and well-spaced with exercises (most typically of the filling in the blank variety) following the introduction of new words - useful if you want to photocopy certain pages to give as handouts (within copyright laws, of course).

The question arises as to whether there is a place for this book, given the widespread use of the internet in schools. There are lots of vocabulary-testing websites where one can add colour pictures and even videos to help students remember the meaning of the text. Moreover, the pictures in this book are entirely in black and white - there is not a single colour picture. While this obviously cuts down on printing costs, this is a factor to bear in mind, when competing with all the colourful pictures which one can get from the internet. Usborne, years ago, had a Latin for Beginners book which was in colour.

The general premise that pictures help students learn vocabulary more than simply plain text is sound. This is used in modern foreign languages and whereas many might claim that pictures should be regarded as differentiation and therefore confined only those who are deemed to have weak reading skills or SEN, I think is misguided. Pictures make it easier for everyone to learn languages. In that sense, this book does have a use, and while many teachers might prefer to use the internet, variety is the key. It should not be the case that one either uses books such as this or the internet: both can be used to stimulate interest. Teachers, however, might want to focus on the more traditional Roman vocabulary in this book for lessons, while 
keeping the modern, colloquial Latin for after-school clubs.

\section{James Tuck, St. Michael's Preparatory School, Otford and Rose Hill School, Royal Tunbridge Wells.}

\section{Literature Johnson (W.A.)}

\section{The Essential Herodotus, New York: Oxford University Press, 2017}

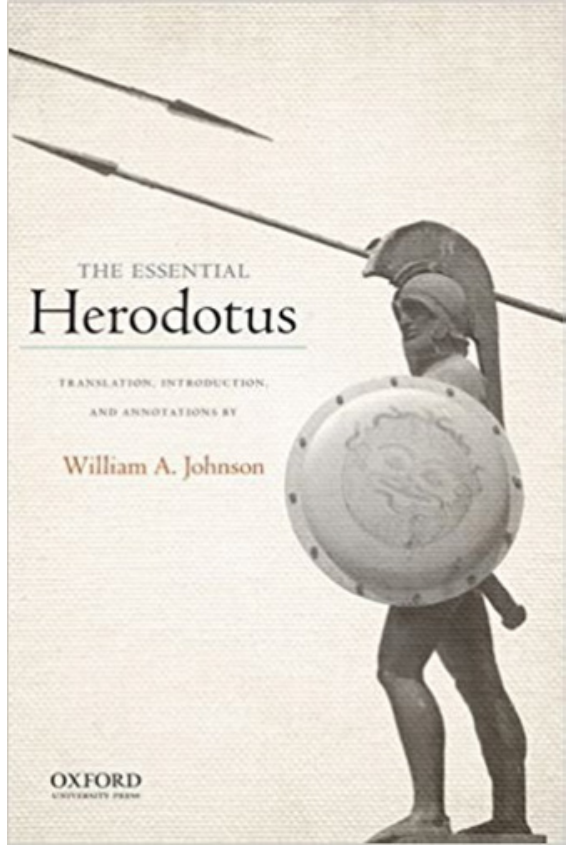

The first thing which struck me about Johnson's premise for producing this condensed edition of Herodotus' work was how much I sympathised with the position he lays out in his preface. His experience with Finlay's The Portable Greek Historians, by which Herodotus is seemingly distorted into a somewhat jovial peddler of historical narratives, interwoven with fun facts from the Ancient World, is undoubtedly one shared by many who approach Herodotus for the first time in a reduced format. His idea, therefore, of producing a slimmed-down edition of the text while retaining the balance of themes and events which Herodotus covers should allow students access to the work without giving a fundamentally different impression of its overall nature. Add to this a number of introductions when the text reaches pivotal moments in the narrative and additional short explanations scattered throughout and Johnson has produced an edition which should help ease the reader into one of the seminal texts of the Classical World. Not only is this an admirable aim, but in many respects he has succeeded.

The main body of the text is made up of translations (written by Johnson himself) of extracts which he has selected in order to achieve the aim set out above. But, before launching into this, he makes time for a very brief introduction in which he considers (among other things) the nature of history, what Herodotus thought he was doing, and how history developed into something with conventions we might recognise (perhaps predictably citing Thucydides as the decisive moment in the crystallisation of the genre). Interestingly, though, Johnson does not claim to have all the answers but sets us off on our journey with a series of thought-provoking questions with the aim of making us consider in greater depth the material with which we are about to interact.

The bulk of the work is divided up into nine sections, roughly (though not exactly) corresponding to the nine books of Herodotus' work, each titled with an overall theme (e.g. Cambyses invades Egypt or The Ionian Revolt) with a short introduction to the events of the section, the historical context, and the major themes in this part of Herodotus' work. Although generally quite brief, like the main introduction, these discussions are useful to the new reader of Herodotus, pointing to areas of interest without explicitly pressuring them to form a particular view. Each of these wider divisions in the work then contains between five and ten substantial extracts which allow the reader to experience enough of Herodotus' writings to obtain a very real sense of the author's style and the overall shape of the work. Johnson's translations themselves are eminently readable while retaining a touch of Herodotean style in the English, faithfully giving a feel for the tone of his work. The extracts are also accompanied by numerous, very helpful, maps of the areas in question along with drawings and images of artefacts, inscriptions and sites of contextual interest or diagrams of battle tactics and troop or ship movements. Combined with Johnson's tables of Lydian, Egyptian and Persian rulers and, at times, extensive footnotes (providing cultural, linguistic, and historical support), the reader should feel equipped for any aspect of the journey. In the early part of the work Johnson's addition of 'some motifs to watch for' (e.g. the wise advisor, the role of fate and oracles, the crossing of a cultural or natural boundary) adds even further to the sense of being guided through the material.

As a result, there is nothing which Johnson has chosen to include with which one could find real fault. Everything is designed to assist the reader in getting to grips with a potentially intimidating text. The difficulty, however, when you take a work like that of Herodotus and embark on a course of slimming it down is less what you choose to include but more the decisions you make as to what to exclude. Of course, at a third of the size of the original, Johnson is bound to have upset someone with his cuttings. For me, though, there are one or two omissions which seem to actively impact on the arc of the work. In terms of the early expansion of the Persian Empire, the choice to include nothing on Babylon, neither the siege by Cyrus nor its recapture by Darius, seems odd particularly given Johnson's fondness for overarching motifs (a number of which are to be found in the character of Zopyrus). Furthermore, the rise of Athenian democracy (pivotal in Johnson's freedom vs slavery debate) and the expulsion of Demaratus from Sparta (disunity among the Greeks being another theme singled out regularly) are also unexpected exclusions from the text. The titling of those extracts from Book IX as a 'Coda' seemed especially disappointing to me considering the cyclical conclusions it contains (particularly concerning Xerxes' somewhat disturbing relations with members of his family). In short, I felt I wanted more: greater discussion of the key themes which Johnson had gone to so much effort to highlight in the early extracts, more information as to how Herodotus' long excursuses fit into the wider narrative, and greater emphasis on the ring composition within the work and the way in which early happenings function as precursors to the main events (Marathon, Salamis and Thermopylae).

Despite this, for a student approaching Herodotus for the first time, they could do far worse than Johnson's work. It is clear that he takes great pleasure in Herodotus and has a considerable desire to draw new readers into the world of our first historian by offering support, encouragement, stimulating questions and ideas for further 
reading and research. Even in a reduced format, it was no less plain to me what had attracted me to Herodotus' writings 20 years ago and it will undoubtedly provide the same stimulation to others.

\section{Neil Treble, King Edward VI School, Stratford-upon-Avon}

\section{Garvie (A. F.)}

The Plays of Sophocles. Pp. $\mathrm{x}+96$. London and New York: Bloomsbury Academic, 2016 (first published 2005). Paper, £14.99. ISBN: 978-1-4742-3335-4.

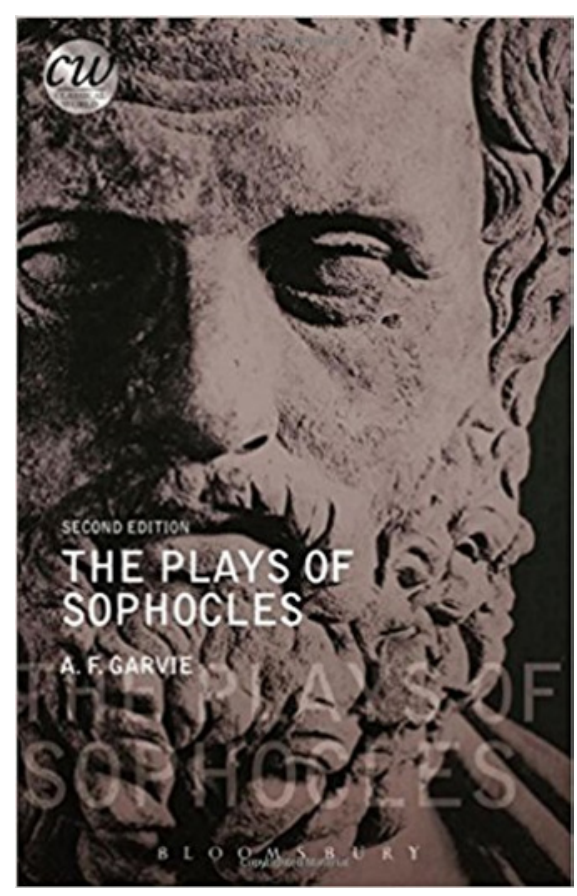

This second edition of Garvie's introduction to Sophocles is an essential read for sixth form and undergraduate students. It provides important information and analysis in an easy-toread style which is accessible to a wide audience. As expected it contains a useful glossary, chronology and suggestions for further reading. This updated version also adds further information on the staging of Sophocles' plays and the role of the chorus. Greek terms are used throughout the book and explained thoroughly.

The book starts with a short introduction that briefs readers on Sophocles' life, dates of his plays and how the plays would have been presented, including notes on the layout of the theatre and the role of the chorus. There are no illustrations and the introduction really just sums up, very briefly, the main points of Greek theatre. For a more robust explanation the companion book, Greek Tragedy, is recommended.

Garvie covers all seven of Sophocles' extant plays. He offers a careful explanation of the plot of each play and discusses the main themes and characters with appropriate analysis for the target audience. There is some discussion of scholars' differing viewpoints on key points within the plays, with some named to enable further reading, if required.

However, not all scholars are identified within the text which may disappoint the more advanced classicist. There is enough information for a student reader.

Garvie readily accepts there is much still unknown about the staging of plays but offers suggestions for how they may have been produced. In the Ajax he concedes that his previous view on Ajax's suicide has changed due to the persuasiveness of others' ideas. This inclusion of differing viewpoints provides some worthwhile debating topics for students to deepen their knowledge and understanding of Greek tragedy.

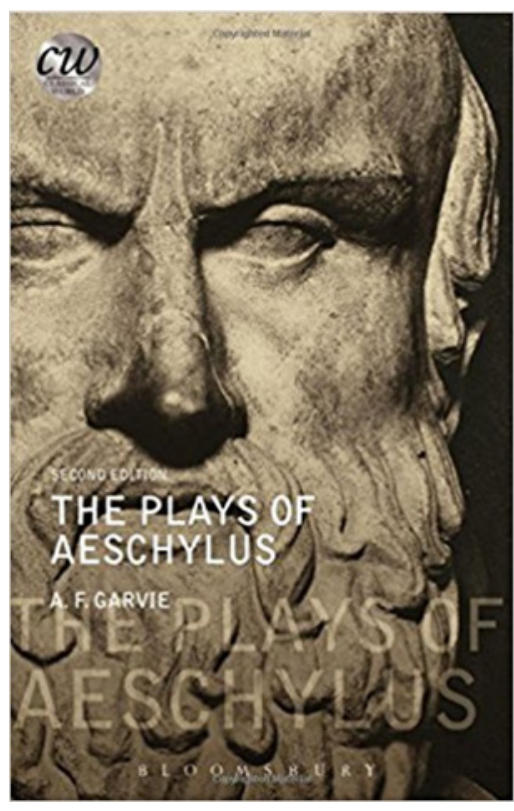

Much has been written about the plays of Aeschylus and Euripides since the first edition of these books (2010 and 2002 respectively) and so it is perhaps time that Bloomsbury issued a second edition in their Classical World series to reflect the recent scholarship. A second edition has also been released of Garvie's 2005 book The Plays of Sophocles, as well as a new
Movement on stage is clearly acknowledged with the identification of the stage entrances and exits and the actors movement through them. The skene is also described well which facilitates interest in staging and how the Greeks conveyed settings. These factors helpfully enable readers to produce their own visual ideas on staging.

Overall a very useful and informative book for students who are studying any of Sophocles' plays.

\section{Denise Batchelor, Loreto College, St Albans}

\section{Garvie (A.F)}

The Plays of Aeschylus. Pp. 99.

London: Bloomsbury Academic, 2016. Paper, £14.99

\section{Morwood (J)}

The Plays of Euripides. Pp. ix +144 , ills. London: Bloomsbury Academic, 2016. Paper, £14.99

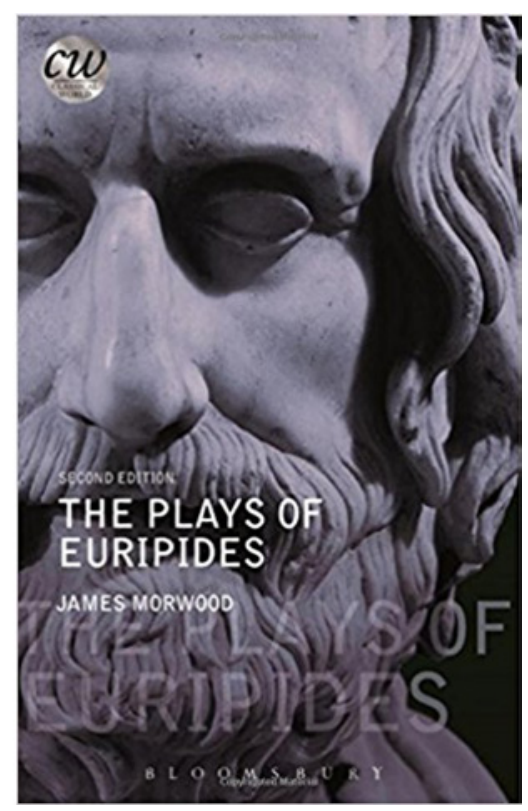

publication by Laura Swift entitled Greek Tragedy: Themes and Contexts (presumably in place of Marion Baldock's introduction to Greek tragedy first published in 1991) so the Classical World series of books is a good starting point for students new to Greek tragic theatre.

Each book starts with a chronology, which helps to place the playwright's work 
in the political situation in which he was writing, as well as giving us details on the outcome of the dramatic competition where this is known, which is useful for prompting discussion on the plays from both an ancient and modern perspective: 'Why did Medea only achieve third place?', for example, might give rise to an interesting discussion of how well that particular play fits tragic convention in the light of Aristotle.

The books then turn to discussion of the plays themselves, each running to no longer than six or seven pages. A summary of the action isn't provided explicitly, but is interwoven throughout the analysis, so there is no 'easy cheat' or 'helpful revision aid' in terms of the plot - the plays must be read! Students should be advised that a scholar's interpretation of a particular moment in a play isn't always necessarily relevant to an examination answer: for example, while the use of nautical imagery is prevalent in Medea, the student must work out for him- or herself how this could be used in a question on Medea's character, for example.

At the end of each play, there are helpful suggestions for further reading, which may be of more use to teachers and undergraduates than sixth formers.

Nonetheless, the lists are short enough to enable a keen sixth former to approach independent research perhaps for the first time, running to no more than three or four items per play.

The end of each book contains an epilogue. In the case of Garvie's book on Aeschylus, it acts as a 'summing up' of the book and provides an overview of Aeschylus' style, as well as his contribution to Greek theatre in terms of the addition of a second actor. On the other hand, Morwood's book offers an epilogue sub-divided into various themes (women, marginalised characters, the Chorus etc.) which gives the student some initial reading for thematic essays, but is by no means comprehensive (not that it claims to be such), running to perhaps a page per sub-division.

As one would expect, there is a brief bibliography at the back of each book, incorporating the 'further reading' suggestions at the end of each play, as well as some more general works which may be useful to the student. As well as this, there is a helpful index, enabling the student to quickly look up, for example, democracy in Aeschylus, and find the required references.

One area in which the two books differ - and it is a small area - is that Garvie's book on Aeschylus contains a useful glossary of terms relating to Greek theatre, which are often transliterations of the original Greek terms (skene, ekekyklema etc.), Of course, such a glossary can always be provided by the teacher, but it is a nice addition in the book for ease of reference.

These are accessible texts and as such they are primarily intended for students studying the texts in translation.

References to the Greek text or matters of metre are very rare indeed. That is not to say that a student who is reading the plays in the original would not find much use for such books, but rather there is no help with the grammar or translating of the text: this is rightly left to many excellent commentaries.

Whether I would rush to buy these if I already had the first editions is debatable: Garvie in his preface to the second edition says that he has been afforded the opportunity to expand certain sections, such as issues of staging in Aeschylus and there are updates to the 'further reading' lists. Nevertheless, if your school library copy (or your own, for that matter!) has seen better days, I would certainly recommend the new editions, as well as the overview of tragedy by Laura Swift to complete the collection.

\section{Andrew Lowe}

\section{Pelling (C.), Wyke (M.)}

\section{Twelve Voices from Greece and Rome.} Ancient Ideas for Modern Times. Pp.xiv +274 , ills. Oxford: Oxford University Press, 2016 (first published 2014). Paper, $£ 12.99$, US $\$ 25$. ISBN: 978-0-19-876803-6.

This book is comprised of 12 voices: 12 authors, six who wrote in Greek and six who wrote in Latin. The choice of authors to illustrate the richness and diversity of the ancient world is not an easy thing; it is a choice bound to excite controversy amongst those whose favourite authors have been left out, but Pelling and Wyke have thought carefully about which authors to choose and, equally carefully, about how to present

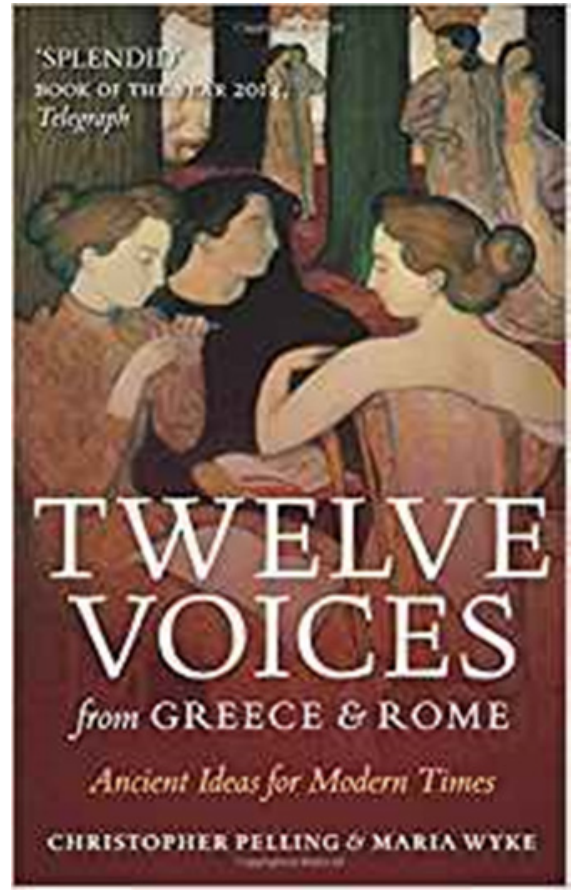

them. As they say in the preface, they are not seeking to present their choices as ways of dealing with the modern world but rather as a chance to think in a 'refreshingly different way - sometimes startlingly alien - way about religion, say, or the East, about happiness, sexuality, power, or the political role of literature'. Chris Pelling deals with the Greek authors and Maria Wyke with the Roman; this works well as we get not only a taste of the ancient author but also a view from the present, and that view is joyful. Chris Pelling's response to his choices is very personal and refreshing: this is not the view of a jaundiced professor but that of someone who is still fascinated by the energy that authors such as Herodotus and Sappho, Thucydides and Euripides still convey. Herodotus is, with his 'infectious curiosity, ... open-mindedness, ... readiness to believe that there may well be a marvel around every new corner' the person that he would most like to be like. Sappho, possibly one of the less well-known figures, is treated with equal joyfulness. We see her as a real person, and at the end of this chapter we hear of a fragment of Sappho's work that had just been discovered. There is evident excitement in this discovery and in the fact that we can hear this work for the first time in over a thousand years. I recall hearing Edith Hall reading it on Newsnight in 2104 and feeling the thrill. Maria Wyke has the more difficult job of 
making that schoolboy classic, the Gallic Wars, fresh and exciting, and she manages it. She points out that the books are not merely handbooks of military strategy but are propaganda par excellence, presenting Caesar as 'the ideal Roman general and dutiful servant of the state.'. This may not come as a surprise to seasoned Classicists but this chapter will be a help to those who may be attempting to justify the choice of Caesar for class reading. Other choices will come as no surprise: no survey of Roman literature is complete without Cicero, and the chapter on Thucydides in the Greek authors is balanced by one on Tacitus. Here Maria Wyke makes a confession that will ring true of many classics specialists of a certain age, that Robert Graves' novels I, Claudius and Clandius the God were a spur to her desire to study Classics, and her parting shot would bring joy to the heart of any historian -'When we read his works, we also understand the importance of writing history. Interpreting the past is a necessary step toward mastery of our future.' Juvenal with his biting wit makes an appearance and in this chapter we hear first of Dr Johnson and his debt to the poet as well as of William Hogarth whose engravings showed a similar eye for 'vivid and provocative microscopic detail'. The collection ends with Lucian, an author who is so often unfairly overlooked. Here we are treated to comparisons with somewhat more modern satire and the Lucian is still fresh! It is a salutary experience for many of us, who think that we are innovative and new in our ideas, that most of them have been done before; but it is an invigorating feeling and one which pervades the whole collection. I would heartily recommend this book for a school library and for general reading in preparation for A Level Latin, Greek or Classical Civilisation. Although there is a certain expectation of prior knowledge, it is not necessary to have an encyclopaedic knowledge of classical literature or history to enjoy Twelve Voices. There is however an engaging energy and honesty in the writing which makes these authors accessible and allows us to see them as part of a continuum which is still active in our own time.

\section{Jo Lashly, Shrewsbury High School}

\section{History and civilisation Rahe (P.A.)}

The Spartan Regime. Its Character, Origins and Grand Strategy. Pp. xvi +212 , ills, maps. New Haven, CT: Yale University Press, 2016. Cased, US\$38. ISBN: 978-0-300-21901-2.

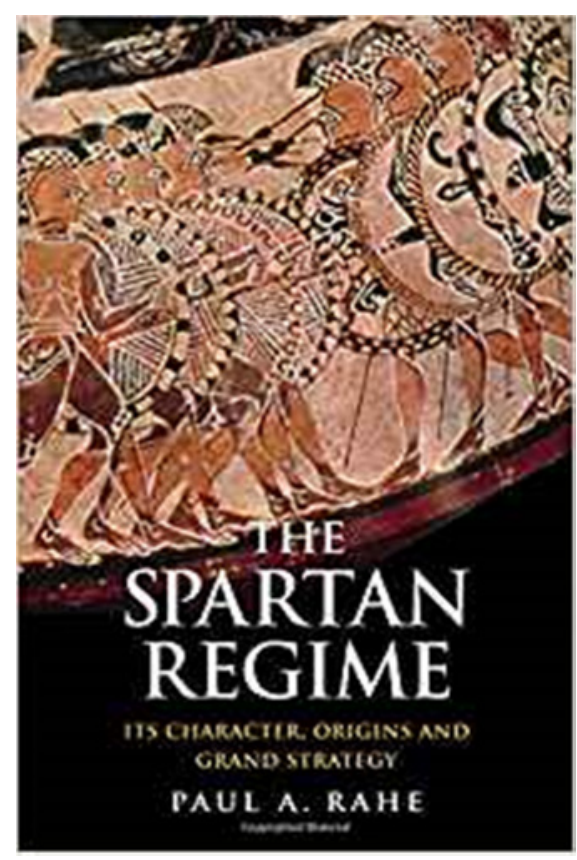

This is not a book for the complete novice, but it is accessible to those who are interested in the very different way that the Spartans ran their lives. As Classics teachers we are most likely to have an 'Athenocentric' view of the ancient world, simply because of the wealth of literature, art and epigraphic evidence that was left behind by those 'quick to form a resolution and quick at carrying it out' (Thuc I:70); we tend to view Sparta as 'other', (despite Xenophon's best efforts) and this book does its best to set in context that 'otherness'. I believe it succeeds. Rahe sets out in his introduction his reasons for concentrating on the Spartans and their allure. He is right, they were, and are, regarded with awe, partly because they were so different from the Athenians and partly because their single-mindedness intrigues us. The Spartan Regime is the first in a projected trilogy and it aims to set the scene, allowing the reader to gain an understanding of Sparta as a whole. As the author says, 'It is only, I believe, when one has seen Sparta whole that one can make sense of her conduct within Hellas in the archaic and classical periods.' Context is everything. We are used to the arguments put forward in say, Lysistrata, where the closed-off nature of Spartan society is satirised or of the stories told by Herodotus of Cleomenes and Leonidas, but it is necessary to go back and discover why and how their society evolved as it did. Rahe attempts to do this, and largely succeeds. With the assistance of maps and a careful trawl through the beginnings of Spartan society, Rahe gives a coherent and, sometimes engaging, account of Sparta and its social and political structures. The book begins with an overview of Spartan society and then moves on logically to the education structures in place. Technical terms are used but they are explained and the writing is accessible with constant explanation as to why things might have been done. For example, with regard to coinage, the Spartans separated the citizen body from the influence of the marketplace for fear that competition would set them at odds. The 'servants of Ares' had no purpose other than to gain a reputation for valour. He moves on to the composition of the state and comments that Sparta was something of an exception in that there appeared to have been no civil strife, although this cuts both ways. There is a clear explanation of the role of the kings and the dangers inherent in the system for them and this is followed by an explanation of the role of the warrior and the background to the growth of the Spartan state. I found the chapter on Politics and Geopolitics the most interesting as, having been to Sparta on several occasions, it is very obvious why and how they became such an inward-looking society. There is much to be said for the view that political cultures are shaped by the terrain in which they appear and Sparta is no different. If you stand on the Menelaion just to the east of modern Sparta and look out over the Eurotas valley it is obvious how the Spartans became the people they were. The land is fertile but enclosed and the rise of the Taygetus mountains in the distance is a clear dividing line between Sparta and the rest. This volume finishes with the conclusion that the system in classical Sparta was designed for the purpose it intended to serve, but that it was too focused on the Peloponnese. Sparta did not adapt to the 'globalisation' 
driven by the Athenians and this was its downfall. The next volumes, I hope, will address this problem. As I said at the beginning, this is not a book for the novice but it will be accessible to those who really want to know something about the Peloponnesians. It is copiously referenced and nicely produced and will doubtless be an invaluable addition to the shelves of those who wish to study the Spartans in relation to those more pushy Athenians.

\section{Jo Lashly, Shrewsbury High School}

\section{Stephenson (P.)}

\author{
The Serpent Column. A Cultural \\ Biography. Pp. xxii + 275, ills, maps. \\ New York: Oxford University Press, \\ 2016. Cased, £47.99. ISBN \\ 978-0-19-020906-3.
}

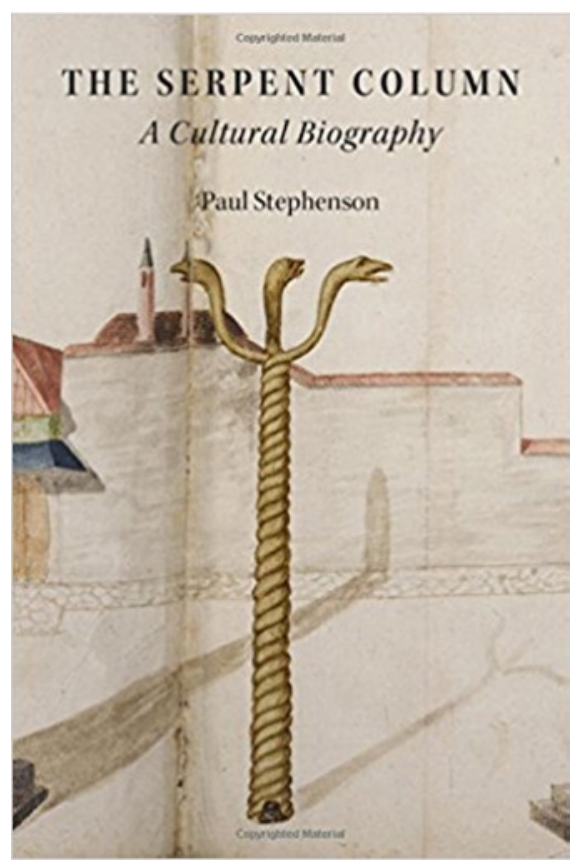

Following the Battle of Plataea in 479 BC, the Greeks (so Herodotus records, 9.81) used a tithe of Persian spoils to dedicate, at Delphi, a monument to commemorate their victory; this took the form of a golden tripod atop a column in the form of a three-headed bronze snake. By the time Pausanias visited Delphi in the second century $\mathrm{AD}$, only the bronze 'serpent column' of this monument remained (10.13); during the reign of the Emperor Constantine, it was transferred to the hippodrome of Constantinople. Now lacking the heads of the snakes, which are said to have become detached from the column in 1700, the monument remains in Istanbul to this day.

The story of the 'serpent column', a summary of which I have just given, is what I expected to find, though of course told in greater detail, in the volume here under review, but that expectation represented a significant underestimation of the scope of Paul Stephenson's monograph. The majority of the book considers the serpent column in Constantinople/Istanbul - actually not a surprise when one considers that it has spent far longer in that city than it ever did at Delphi - and therefore takes classicist readers into many areas with which they are likely to be unfamiliar.

The book begins with an overview of the scholarship on the monument and introduces the reader to its different elements, including the inscription on the coils of the serpent column, which recorded the names of those cities 'who fought the war' against the Persians. It is in this chapter that the reader discovers that the serpent column, during its time in Constantinople, served as a fountain - an aspect of the monument taken up fully in chapter 6 .

Chapter 2 offers a summary of the Persian Wars, inevitably focusing on the Battle of Plataea itself, before turning to a fascinating series of reflections on why this monument at Delphi may have taken such an unusual, serpentine form.

Modern technology allows a re-creation of how the night sky would have looked above Plataea prior to the battle. 'Looking to the sky, the Greeks saw a coiling serpent in the grip of its handler, its head reaching above the spiralling Milky Way. They also saw Draco plunging to earth where the Persians were encamped' ( $p$. 42): a possible inspiration for the design of the serpent column is thereby revealed. The author then discusses the mythology of both Typhon and Python and how these stories too may have informed the choice of the serpent column's form. The following chapter continues to consider the early life of the monument, with a discussion of bronze-working followed by an exploration of a number of lines of enquiry, chief amongst which is consideration of the role of the Spartan regent, Pausanias.

Subsequent chapters not only tell of the serpent column itself after its removal from Delphi but also consider both how it may have been received and how it may have influenced those who saw it. Particularly intriguing is the possibility that the monument (and drawings of it) may have influenced the form of Christian images of serpents; equally interesting is the revelation that the serpent column may owe its long survival to becoming regarded as a talisman that protected the city and its inhabitants from snakes. These chapters, as with the volume as a whole, are illustrated with black-and-white images which include photographs, maps and plans, as well as several re-creations of the night sky on particular dates in antiquity.

The author acknowledges in his preface that his 'chapters often proceed by inference and suggestion, by the accumulation and conjoining of discrete elements, rather than the systematic manufacture of a singular and convincing argument' (p. xii). This approach can prove challenging for a reader who is led away from ground on which they feel secure, but it is ultimately rewarding for them as they are made to realise that a monument they may know only from the text of Herodotus has been and remains much more than just a memorial to a conflict between Greeks and Persians. Justifying calling his work a 'cultural biography', Stephenson remarks that 'through its life history, its biography, the manner in which it [the serpent column] has been received has been dependent on cultural redefinition, whether by its being moved or by its observers moving through time and space' (p. xiii). The reader of this book is also taken through time and space, and will finish this book having learned about the cultures in which the serpent column was created and has been received at least as much as they have learned about an object made around 2,500 years ago.

\section{James Watson, The Perse School, Cambridge}

\section{Toner (J.)}

\section{Release your Inner Roman by Marcus Sidonius Falx. Pp. $\mathrm{x}+230$. London: Profile Books, 2016.}

Having been intrigued by the title, and the 'self help' format of the book, I was delighted to have the chance to read and 


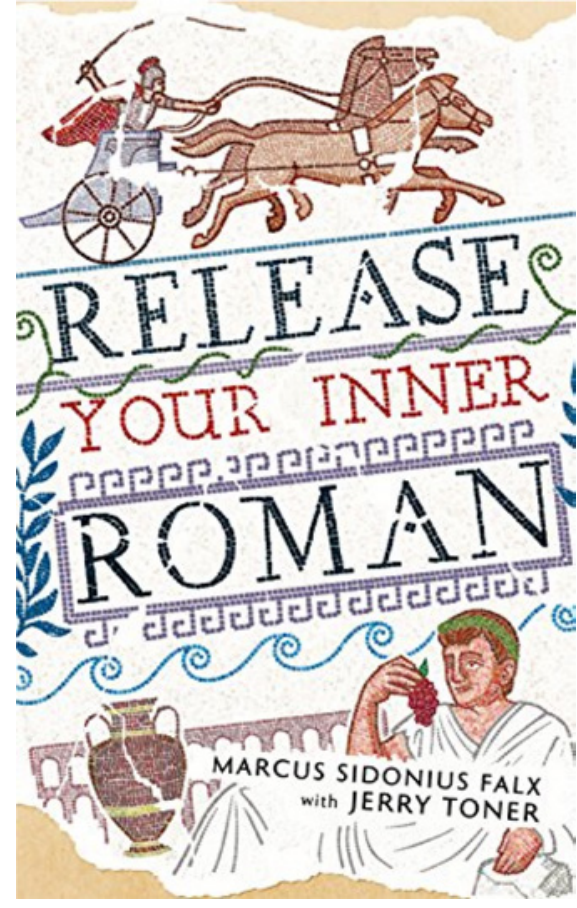

review it and was not disappointed.

Engaging from the start, it is packed full of interesting stories and facts to keep the reader entertained throughout.

Dr Jerry Toner has returned to the persona of Marcus Sidonius Falx, which he created for his previous book How to Manage Your Slaves. Marcus is a 'largerthan-life character' and a Roman of noble birth who 'writes' much of the book outlining his own experiences of life in Rome. Ostensibly written as a self help guide to enable the reader to 'raise himself up in society and keep the gods on his side', this approach allows Marcus to provide a fast-paced introduction to life in the ancient city. Without being slowed down by references to sources or specific detail, the format means that a wide range of topics can be covered, with advice on everything from marriage customs to a visit to the baths and discipline in the Roman Army. Each of the nine chapters addresses a different part of daily life, starting in the first chapter with the 'habits of highly heroic Romans', detailing a number of displays of heroism from Rome's past, to chapters on marriage, moving up the career ladder, managing your household and all the best medical advice Rome had to offer.

Despite the light-hearted approach, the book still introduces the reader to a number of historical figures and factual information in a memorable manner. At the end of each chapter, Toner outlines the facts behind the narrative from
Marcus, as well as naming the texts he has used for inspiration, which adds weight to the information delivered in a more casual manner. There is an additional list of further reading at the end of the book which is more comprehensive than in the chapter summaries. As an introduction to the Roman world this is an interesting read that would encourage the audience to look for more, and it does rely heavily enough on the texts of ancient authors to be valuable to the reader. However, the information is only presented from Marcus' point of view and has been carefully selected because it is interesting and attention-grabbing. Whilst there are plenty of swords and sandals moments to keep any would-be Classicists engaged, I would suggest the chapter about how to 'romance like a Roman', with its detail on the sex habits of emperors, is a little too much for GCSE students!

With the attention-grabbing title and quirky format, this book is a thoroughly enjoyable read on life in classical Rome and is packed full of information and interesting personalities to draw potential students into the classical world.

Caron Downes, The Mount School

\section{Taylor (R.), Rinne (K.W.), Kostof (S.)}

\author{
Rome: An Urban History from
}

Antiquity to the Present. Pp. xvi +432 , ills, maps. Cambridge: Cambridge

University Press, 2016. Paper, £24.99,

US\$39.99 (Cased, £69.99, US\$120). ISBN 978-1-107-60149-9.

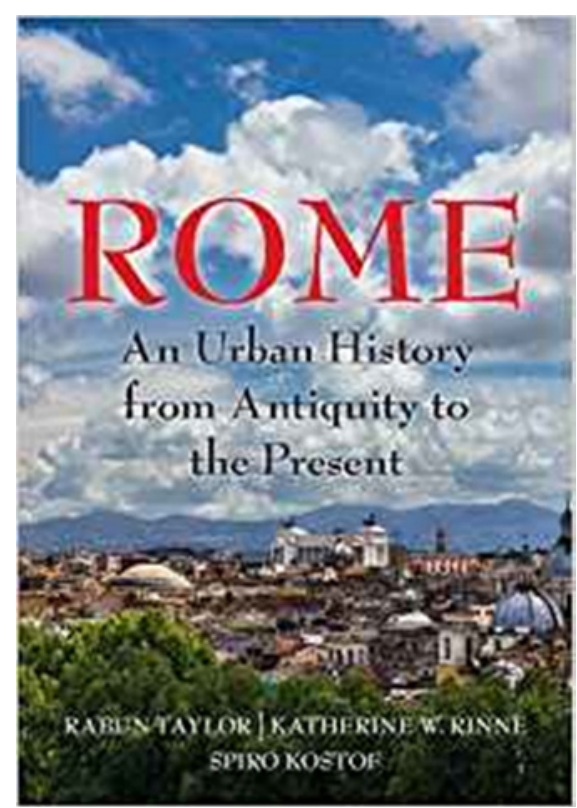

In the first chapter of Civilization and its Discontents, Sigmund Freud likened the urban history of Rome to the knowledge that might be had of it by someone (like him) who has made a serious study of the city. This was not precisely his intent; but the passage came to mind as I began my study of this book, and remains there. Freud first summarises what he'd learned from historians of Rome, and then describes what he'd seen on his visits to the city. He goes on to imagine all the buildings, walls, and monuments ever erected in Rome, existing all at the same time. He soon gives over this 'phantasy', not because he has exhausted his

knowledge of Roman history, nor because his imagination has exceeded his ability to write about it; but because he feels he has sufficiently demonstrated the limitations of pictorial representation. A history of the city of Rome would seem to need to rely heavily on pictures; and today's visual technologies would seem to be all any students or teachers would need to cover the urban history for purposes of teaching and learning. But Freud's point, I think, is one borne out by this book: we won't come to know Rome just by looking at pictures of it; we won't come to understand the urban history unless we study such substantive and articulate historiography as this.

That said, I must add that this history of the city makes very good use of a great many pictures. The old saying is that a picture is worth a thousand words; and what is usually meant by it is that the picture can take the place of the words, and tell as much. The pictures we come across as we read this history rather illustrate the idea that it takes a thousand words (more or less) to contextualise and explicate a significant picture. We see (and so can read) maps (both ancient and modern); models (constructed at, and representative of, particular moments in Rome's history); architectural and otherwise schematic drawings; artistic engravings especially from the Renaissance and Enlightenment, two periods particularly interested in, and of particular interest to, the history of Rome; photographs both early and up-to-date; and images representing what digital technology can do to show what Rome might have looked like when the archaeological ruins were new. The narrative and analysis to which the illustrations are attached do not explicitly 
indicate the reading I have suggested; but I would suggest that that reading is available to any instructor who might use this book to teach the history of the city of Rome. It would, I think, enhance the students' view of the pictures, and engage them in a more critical reading of the text.

The text has come together - rather as the city has - over time and under the guidance of several hands. The work began with a set of lectures on Mediaeval Rome delivered by Spiro Kostof at Columbia University in 1976. Rabun Taylor has added the chapters on the ancient, and Katherine W. Rinne those on the modern history of the city of Rome. They cover everything Roman, from the archaeological to the architectural to the environmental features of the city's history. This is not a history of the Roman Republic, or Empire, or Church; but the chronological trajectory of the chapters, as well as the role played in Rome's development by Emperors and Popes, makes it possible to map this history over the more familiar one. More narrative chapters covering, for example, just how Augustus found Rome a city of brick and left it one of marble, are interspersed with ones uncovering (say) the analytical details of urban administration or the prevention and remediation of fire and flood damage. I have been especially impressed with the ways in which the narrative and analysis present a compelling account of what is known about Rome, alongside an acknowledgement of what is not or can't be known. The text does not just reflect the state of knowledge of Rome's urban history; it represents the production and deployment of it - which is a useful thing for a textbook to do. It shows students how the history is written, whereas watching a virtual tour doesn't show them how to do the coding.

This history does cover Rome from antiquity to the present, and so may not be an ideal fit for a course whose description or syllabus covers only classical Rome. On the other hand, I can't think of a better resource for students who are actually studying in Rome. The narrative and analysis of the urban history, along with the scholarly bibliography, should give them a good start in researching any of the features of ancient Rome they will see when they get there. I am going to be sure to hand my copy on to the director of my college's Rome program.

\section{B. C. Knowlton, Assumption College}

\section{Art and architecture Zaphiropoulou (P.N.)}

Classic Greek Masterpieces of Sculpture. pp. 256, ills. New York: Abrams Books, 2016. Cased US\$30. ISBN: 978-1-4197-2229-5

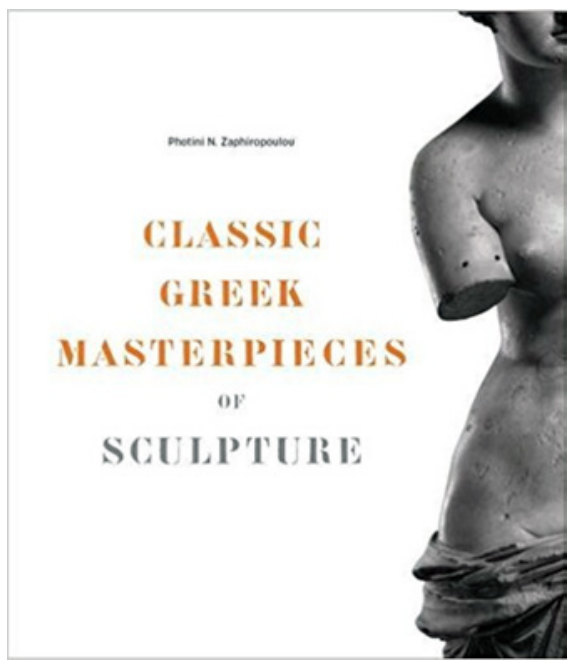

This book is a joy to look at, both for the enthusiastic amateur of Greek sculpture and for the serious scholar. I say to 'look at' advisedly, because it is above all the quality of the photographs which makes this book something special. With so many good colour photographs of museum pieces readily accessible on the internet, one might wonder whether there was a need for a book consisting largely of photographs, all monochrome, with little text. However, this book provides something not readily available, namely extremely high-quality images often focused on small details of the whole statue - the ear of a kouros, for example, or a single sandalled foot of Praxiteles' Hermes. The clarity and intensity of the black and white image also brings out the depth of the material, often lost in two dimensional images of three dimensional objects. Much work has been done recently on exploring the original colour of some of these pieces, and this is referred to in the text. The range of pieces selected is extended, from a sixth century BC kouros to a first century BC wall plaque; in between, in chronological order, are some very well-known pieces - the Delphi charioteer, the Nike of Samothrace, to name but two - and some far less familiar, such as the fragmentary part of a male figure from Paros Archaeological Museum or the Hellenistic Nymph from the Delos Archaeological Museum.

Quite apart from the excellence of the photographs themselves, the book is attractively set out in a good format: large enough for good-sized pictures, but not so large as to be unwieldy. Standard reference and index material - title, provenance, date, material, dimensions, collection - is given clearly for each sculpture. Given the focus on specific details, it is essential to have the overall size of the piece given, or it could be very misleading. This book does not disappoint, giving dimensions in both imperial and metric; I would advise any teacher using this book in the classroom to have a tape measure handy. What is missing, however, is that although the collection is given, the accession number is not, which makes it hard to track down the less well-known pieces for further study. Anyone wanting to find out more about the kore illustrated on page 72 , for instance, armed with only the information that it is from the collection in the Acropolis Museum will have a long time finding it. This may seem a quibble, but any serious scholar at A Level and above will want to read more than the limited text on offer here. Each sculpture has a paragraph or two drawing the reader's attention to the main features of note, while there is a slightly more extended introduction to pieces of architectural sculpture to explain the context of the site as a whole. These descriptions are economical and are at their most successful when they remain purely objective comment, a good guide for students in describing a piece of sculpture. Some of the more subjective comments can get in the way, as in the case of the Samos Kouros, where the final comment is: 'All that remains of this likely powerful man are his name and the artistic masterpiece he dedicated, which continues to delight all who see it: Hic jacet gloria mundi.' It would have been more useful to include his name - Isches son of Rhesis - which, as the text tells us, we know from the inscription running up his left thigh, and would have made an interesting photograph in itself. Again, 
the section on the Parthenon frieze describes the procession as a Panathenaic procession, but without any reference to the different interpretations of the central scene over the east doorway. Teachers will want to direct students to fuller accounts of the problems of interpretation. That said, there is a useful and accessible essay giving an overview of the development of Greek art at the beginning of the book, by Stelios Lydakis, Professor Emeritus of History of Art at Athens, which students would benefit from reading, although they should be aware that a number of the pieces he mentions do not feature in this book.

These criticisms however largely relate to minor details. I thoroughly recommend this book to schools and colleges teaching Classical Civilisation to have in their library; I would use it in the classroom for focused discussion of how to look at sculpture, and I shall have a copy on the coffee table for the sheer pleasure of looking at beautiful images.

Frances Shaw, James Allen's Girls' School 